\title{
Efficacy of Meditation in Managing Craving and Withdrawal Symptoms Among Kashmiri Cannabis Users
}

\author{
Irfan Ahmad Wani* and Bhupinder Singh \\ ${ }^{1}$ Department of Psychology, Barkatullah University, Bhopal
}

Submission: December 28, 2018; Published: January 28, 2019

*Corresponding author: Irfan Ahmad Wani, Research Scholar, Department of Psychology Barkatullah University Bhopal

\begin{abstract}
The present study tries to investigate the efficacy of meditation in managing craving and withdrawal symptoms among Kashmiri cannabis users. The sample consisted of 40 Muslim male cannabis users between the age group 14-35 years taken from drug de-addiction and rehabilitation center police control room Srinagar. The pre and post-test design was used with the standardized psychological tests namely Marijuana craving scale short form developed by [1] and the withdrawal scale developed by Allsop et al. [2] The results showed significant differences on all the four dimensions of craving namely as compulsivity, emotionality, expectancy and purposefulness and also on both the dimensions of the withdrawal symptom scale. Thus, it is concluded that meditation can be effectively used as a tool for de-addiction of cannabis users.
\end{abstract}

Keywords: Cannabis use; Meditation; Craving and Withdrawal symptoms

\section{Introduction}

In Islamic context Meditation namely as (Ziker or Dikhr) is the name of devotional acts in which repetitive utterances of short sentences glorifying Allah [3] are recited silently within the mind or aloud. The content of the prayers includes the Allah (SWT) or (prayer of supplication) taken from the hadith or the Quran. Rarely, it is counted on a string of beads or a set of prayer beads. Islamic Meditation (Holy Ziker) is a bedrock and foundation of a life based in continual personal and spiritual growth and development [4]. There are so many verses in Quran regarding the (Ziker or Dhikr) such as in (chapter 8 (Al-Anfal) Verse 45)., (Chapter 13 (Ar-Rad) Verse 28), (Chapter 33 (Al-Ahzab) Verse 35), (Chapter 4: Verse 190)., (Chapter 39 (Az-Zumur) Verse 23), (Chapter 29 (Al-Ankabut) Verse 45), (Chapter 63 (Al- Munafiqun) Verse 9), (Chapter 20 (Taha) Verse 124)., (Chapter 72 (Al- Jinn) Verse 17)., (Chapter 58 (Al- Mujadilah) Verse 19), (Chapter 39 (AzZumur) Verse 22), (Chapter 43 (Az-Zukhruf) Verse 36). Relating any kind of substance abuse or intoxication in the perspective of Islamic theology "Quranic" verses concerning intoxication such are in (Surah Nisa (Women), verse no. 43), Surah Bagharah (cow), verse no. 219),(Surah Maidah (food), verses 90 \& 91) and (Surah Araf, "The heights" verse no. 31) concluded that wine, gambling, praying idols, lottery are prohibited and are considered devils work. In [3] "every intoxicant is like wine and every wine is prohibited", so many psychedelics such as hashish, cocaine, LSD, amphetamines, mescaline, etc. which intoxicate man like alcohol can be interpreted as prohibition. Babazadeh [4] mentioned that Imam Musa-Ibn-Jafar states: "God has forbidden wine not for its name, but for its effects and corruptions". (Foro Kafi, volume, 6, p 212).

Al-Bukhari and Muslim narrate a certified narration from our Holy Prophet as follow: "God has forbidden these to you: despising parents, burying girls alive, committing treason against trust, and what God hates and does not like you to do like vain talks, continuous suspicion, and wasting money" [5]. Looking at this narration, we conclude that God may hate the obvious evidences of wasting money like drinking wines, narcotics, and even tobacco which impose not only body injuries, but also heavy economic harms on the users, their families, and the society Ibn Kathir, Verse 35:2 [3]. Muslims should avoid of smoking and drug abuse because of many adverse effects of drugs and smoke and referring to some verses of Quran and some hadith, which have forbidden the malevolence Sattari et al. [6]. Meditation refers to an extremely wide variety of practices differs enough from each other so that as of today no clear definition of necessary and sufficient criteria for meditation exists that has achieved universal or widespread acceptance Lutz et al. [7].

Meditation can be conceptualized as a family of complex emotional and attentional regulatory practices affecting mental events by engaging a specific attentional set and has been developed and practiced for various reasons, including the 
cultivation of well-being and emotional balance and for religious purposes Raffone and Srinivasan [7-9]. The longer a person had practiced meditation, the more likely it was that he had decreased or stopped his use of marijuana Shafil et al. [10]. A mantra can be a religious or mystical sound, a word, a sentence, or a poem to calm and focus the mind and body Braboszcz et al. [11].

The sensations induced by the sound of the mantra are believed to calm the mind and body without the need for intense concentrative efforts and are believed to result in profound relaxation, marked by breath quiescence, and reduced conceptual content Travis et al. [12]. Meditation has been described as both a practical method of attaining deep relaxation and as a spiritual path toward the attainment of enlightenment and a procedure to deal with a variety of health-related problems including pain management, hypertension, and muscular disorders and also develops mindfulness at physical, psychological, and spiritual levels Marlatt \& Kristeller [13]. Meditation acts as a form of counter conditioning, in which a state of meta-cognitive awareness and relaxation replaces the positive and negative reinforcement previously associated with engaging in the addictive behavior. In this sense, mindfulness may serve as a positive addiction Glasser [14]. On a practical level, meditation can be used as a technique that elicits a hypo metabolic state of mental and physical relaxation that has been documented to reduce tension and mitigate reactions to stress Benson [15]. Thus, the present study will help to manage the greater indulgent of the result of meditation in managing craving and withdrawal symptoms of cannabis users and facilitate to spot the gaps in the current literature.

\section{Aim}

The aim of the present study is to evaluate the effect of meditation in managing craving, and withdrawal symptoms in cannabis users.

\section{Hypothesis}

There will be significant differences among cannabis users before and after meditation in craving and withdrawal symptoms

\section{Design}

A clinical study in which a group of cannabis users were specified for meditation at least 40 days and by administering Marijuana craving and cannabis withdrawal before and after meditation. In the present study meditation was taken as sovereign variable and craving, withdrawal symptoms were taken as dependent variables. The design of research is as follows (Table $1)$.

Table1: The design of research is as follows.

\begin{tabular}{|c|c|c|c|}
\hline Group & Pre-test & Intervention & Post-test \\
\hline $\begin{array}{l}\text { Cannabis users } \\
\qquad(40) \\
\text { Muslim male }\end{array}$ & $\begin{array}{c}\text { Administration of Marijuana } \\
\text { Craving and Cannabis } \\
\text { withdrawal scales }\end{array}$ & $\begin{array}{l}\text { Meditation (40- days) } \\
\text { 1. Islamic prayer (Salat or Namaz } 5 \text { times) } \\
\text { 2. First Qalima } \\
\text { 3. Third Qalima } \\
\text { 4. Fifth Qalima }\end{array}$ & $\begin{array}{c}\text { Administration of Marijuana } \\
\text { Craving and Cannabis } \\
\text { withdrawal scales }\end{array}$ \\
\hline
\end{tabular}

\section{Methodology}

\section{Sample}

The incidental purposive sampling technique was used in the selection of the sample. A single group of 40 Muslim male cannabis users between the age group 14-35 years taken from drug de-addiction and rehabilitation center police control room Srinagar Kashmir. Tools use Marijuana craving scale short form (MCQ-SF): The MCQ-SF was developed by Heishman et al. [1] based on 12- item and all items are scored on 1 to 7-point scale alternatives, with four factors such as compulsivity, emotionality expectancy and purposefulness varied from strongly disagree to strongly agree.

MCQ-SF measures compulsivity (inability to control marijuana use), emotionality (expecting use to reduce negative emotion); expectancy (expecting use to have positive outcomes), and purposefulness (intention and planning to use for positive outcomes).The Cannabis Withdrawal Scale: The Cannabis withdrawal scale was developed by [2] based on19 items with three-point scale alternatives and is used to assess the withdrawal intensity and negative impact of withdrawal in cannabis users.

\section{Procedure}

40 days meditation course with Islamic prayer (Namaz or Salat) cannabis users were given the opportunity to attend orientation meetings regarding participation in the course offered by facility staff and meditation clinicians. All cannabis users residing at drug de-addiction center police control room Srinagar Kashmir within one week prior to an upcoming meditation course were recruited by research staff to participate in a study on the effects of meditation in managing craving and withdrawal symptoms and other rehabilitation programs on cannabis use or abuse related consequences, psychological functioning and spirituality. It was made clear to the inmates that participation in the meditation course did not require volunteering for the research study and that being in the research study did not require taking the meditation course. 
The patients fallowed the meditation 7 times per day. The first component of meditation is based on five times Islamic prayer (Salat or Namaz) such as pre-dawn (Fajr), noon (Zuhr), afternoon (Asr), sunset (Maghrib) and around nightfall (Isha). Offering Islamic prayer (Namaz or Salat five times per day) is one the important and essential component of meditation technique whereas the second component of the meditation is (Dikhr) based on recitation of first, third and fifth Qalima 100 times each Qalima per day and sent greeting to Prophet Mohammad (SAW) 100 times per day up to the last day of meditation course. The patients recite these four meditation phrases 100 times each conjointly twice in a day (after pre- dawn prayer and after afternoon (Asr prayer). The below mentioned phrases are the part of second component of the meditation.

a) There is none worthy of worship but Allah (SWT), Muhammad (pbuh) is his prophet and messenger. (First Kalima: 100 times in morning and 100 times in evening).

b) Glory is for Allah and all praises for Allah and (there is) none worthy of worship except Allah and Allah is the greatest and there is no might or power except from Allah, the Exalted, the Great one.

c) I seek forgiveness from allah, who is my creator and cherisher, from every sin I committed knowingly or unknowingly, secretly or openly. I also seek his forgiveness for all sins which I am aware of or not aware of. Certainly You (O Allah), are there is no power and no strength except from Allah, the highest, the Greatest.

d) Allah Bestow favors or blessings upon Muhammad (pbuh) and on the family of Muhammad (pbuh) as you showered blessings upon Ibrahim (A.S) and on the family of Ibrahim (A.S) Surely, you are the praise worthy, Glorious.

\section{Result and Discussion}

Table 2: Depicts the Mean, SD and t-value on marijuana craving scale $\mathrm{P}<0.01^{* *}, \mathrm{df}=38$.

\begin{tabular}{|c|c|c|c|c|c|}
\hline \multirow{2}{*}{ Marijuana Craving Scale } & \multicolumn{2}{|c|}{ Pre-test } & \multicolumn{3}{c|}{ Post- test } \\
\cline { 2 - 6 } & Mean & SD & Mean & SD & t-value \\
\hline Compulsivity & 17.4 & 2.9 & 3.5 & 0.91 & $21.64^{* *}$ \\
\hline Emotionality & 19.08 & 1.95 & 3.76 & 1.66 & $26.31^{* *}$ \\
\hline Expectancy & 19.1 & 2.29 & 3.68 & 1.14 & $32.41^{* *}$ \\
\hline Purposefulness & 19.68 & 1.70. & 3.32 & 0.74 & $50.18^{* *}$ \\
\hline
\end{tabular}

Table 3: depicts the Mean SD and t-valves on cannabis withdrawal scale.

\begin{tabular}{|c|c|c|c|c|c|}
\hline $\begin{array}{c}\text { Cannabis Withdrawal } \\
\text { Scale }\end{array}$ & \multicolumn{2}{|c|}{ Pre-test } & \multicolumn{3}{c|}{ Post- test } \\
\hline Factors & Mean & SD & Mean & SD & t-value \\
\hline Withdrawal Symptoms & 1.25 & 23.32 & 41.04 & 12.35 & $15.34^{* *}$ \\
\hline $\begin{array}{c}\text { Negative impact of } \\
\text { withdrawal }\end{array}$ & 1.12 & 32.43 & 17.20 & 9.36 & $15.36^{* *}$ \\
\hline
\end{tabular}

The t-test was applied to the obtained data to scrutinize the significance of a difference on single group of cannabis users on Marijuana craving and withdrawal symptoms scale (Table 2 \& 3) (Figure 1 \& 2) respectively. The result showed the values of compulsivity, emotionality, expectancy and purposefulness of craving scale decreased in post-test analysis in comparison with pre-test analysis among cannabis users. Coherently, the levels of withdrawal intensity and negative impact of withdrawal decreased in post-test analysis in accord with pre-test analysis among cannabis users. The " $\mathrm{t}$ " value on craving scale factors and cannabis withdrawal scales factors showed significant differences at $(\mathrm{p}<0.01)$.

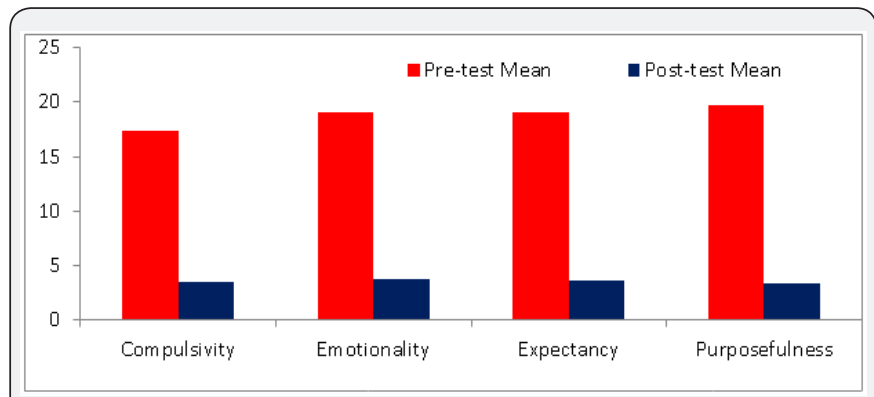

Figure 1: Depicts Mean values on marijuana craving scale.

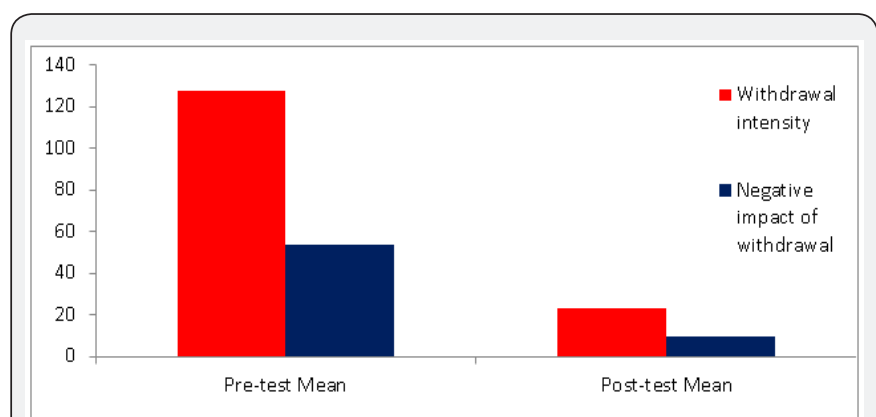

Figure 2: depicts the mean values on cannabis withdrawal scale.

Table 2 and Figure 1 indicates that the cannabis users have obtained lesser mean score on marijuana craving scale factors in post- test in comparison with pre-test analysis. In compulsivity factor of marijuana craving scale, the cannabis users showed higher mean scores in pre-test $(\mathrm{M}=17.40 \mathrm{SD}=2.90)$ as compared with post-test analysis ( $\mathrm{M}=3.5, \mathrm{SD}=.91)$. In Emotionality factor the cannabis users showed higher mean scores in pre-test analysis $(M=19.08, S D=1.95)$ in comparison of post-test analysis $(M=3.76$, $\mathrm{SD}=1.66)$. In Expectancy factor the cannabis users showed higher mean scores in pre-test analysis $(M=19.1, S D=2.29)$ in context with post-test analysis $(M=3.68, S D=1.14)$. In purposefulness factor of craving scale $(\mathrm{M}=19.68, \mathrm{SD}=1.70)$ in pre-test analysis) and $(M=3.32, S D=.74)$ post-test analysis) respectively. Early researches in line indicated that Mindfulness-based relapse prevention (MBRP) affects numerous brain systems associated with decreased craving, negative affect, and relapse, and improved impulse control, and it may repair the neural changes 
associated with addiction and relapse Witkiewitz et al. [16]. Literature revealed that Mindfulness based relapse prevention specifically targets cravings, a significant predictor of substance use and relapse following treatment for SUD Witkiewitz et al. [17] Meditation has been shown to increase gray matter in prefrontal cortex and insula and has been hypothesized to compensate for addiction-induced gray-matter loss Witkiewitz et al. [17]. Mindful attention also reduced neural activity in a craving-related region of subgenual anterior cingulate cortex and its connectivity to other craving-related regions, including ventral striatum and insula Westbrook et al. [18].

Table 3 \& Figure 2 indicate that the cannabis users have obtained higher mean score on withdrawal scale factors in posttest in comparison with pre- test analysis. In withdrawal intensity dimension the cannabis users showed higher mean scores in pretest analysis ( $M=1.25, \mathrm{SD}=23.32)$ in accord with post-test analysis $(M=41.04, S D=12.35)$. In negative impact of withdrawal factor the cannabis users showed higher mean scores in pre- test analysis $(M=1.12, S D=32.43)$ in comparison with post-test analysis or after therapy $(M=17.20, S D=9.36)$ [19]. Literature revealed that the proportion of patients reporting cannabis withdrawal in recent treatment studies has ranged from $50-95 \%$ and commonly experienced sleep difficulty; decreased appetite and weight loss; irritability; nervousness and anxiety; restlessness; and increased aggression Budney et al. [20,21]. In perspective of therapeutic interventions, the meditation practice may also help patients discern and accept unusual physical sensations easily confused with withdrawal symptoms and it may help patients to develop the ability to maintain perspective in response to strong emotional states and mood fluctuations Skanavi et al. [19].

\section{Conclusion}

The present study concluded that compulsivity, emotionality, expectancy and purposefulness withdrawal intensity and negative impact of the withdrawal decreased due to the meditation based on Islamic theology. As for as demography and prevalence of drug addiction in Jammu \& Kashmir is in a deteriorate conditions. However, school and college going students were victimized, as it becomes daily routine to remain intoxicated. The disease of addiction spreading in such a pace no such place like school and colleges are safe, a door step problem for every parent to protect their children. The government of Jandkshould take an initiative step to make religious books like Quran Shareef, Vedas, Geeta, Guru Granth Sahib and Bible a core subject whether in government or private schools or colleges to endow the spiritual part of the personality, as it is more important having counselors in schools or colleges in enhancing personality development and better carrier choices in the students. Thus, it is also suggested that Meditation, yoga or other psychological techniques can be effectively used as a tool for de-addiction process. Clinicians should take the advantage of faith-based intervention programmed to treat substance disorders.

\section{References}

1. Heishman SJ, Evans RJ, Singleton EG, Levin KH, Copersino ML, et al. (2009) Reliability and validity of a short form of the Marijuana Craving Questionnaire. Drug Alcohol Depend 102(1-3): 35-40.

2. Allsop DJ, Norberg MM, Copeland J, Fu S, Budney AJ (2011) The cannabis withdrawal scale Development: Patterns and predictors of cannabis withdrawal and distress. Drug Alcohol Depend 119(1-2): 123-129.

3. Quran Tafsir Ibn Kathir (2009) None can withhold the Mercy of Allah. Tafsir Ibn Kathir Verse 35: 2.

4. Babazadeh AA (2007) Islam's sight about drug addiction. Keyhan 19026: 7.

5. Sahih Al-Bukhari (2002) On Intoxicants 3: 429.

6. Sattari M, Mashayekhi S, Mashayekhi S (2012) Islam and Addiction. Pharmaceutical sciences 18(3): 151-158.

7. Lutz A, Slagter HA, Dunne JD, Davidson RJ (2008) Attention regulation and monitoring in meditation. Trends Cogn Sci 12(4): 163-169.

8. Raffone A, Srinivasan N (2010) The exploration of meditation in the neuroscience of attention and consciousness. Cogn Process 11(1): 1-7.

9. Cahn BR, Polich J (2006) Meditation states and traits: EEG, ERP, and neuroimaging studies. Psychol Bull 132(2): 180-211.

10. Shafil M, Lavely R, Jafe R (2006) Meditation and marijuana. The american journal of psychiatry.

11. Braboszcz C, Hahusseau S, Delorme A (2009) Meditation and Neuroscience: From Basic Research to Clinical Practice. Integrative Clinical Psychology, Psychiatry and Behavioral Medicine: Perspectives, Practices and Research: Springer Publishing Company pp. 1910-1929.

12. Travis F, Haaga D, Hagelin J, Tanner M, Arenander A, et al. (2010) A self-referential default brain state: patterns of coherence, power, and eLORETA sources during eyes-closed rest and Transcendental Meditation practice. Cogn Process 11(1): 21-30.

13. Marlatt GA, Kristeller J (1999) Mindfulness meditation. Integrating spirituality in treatment: Washington D.C American Psychological Association pp. 67-84.

14. Glasser W (1976) Positive Addiction. Oxford, England: Harper and Row.

15. Benson H (1975) The relaxation response. NYPL William Morrow, New York, USA

16. Witkiewitz K, Bowen S, Douglas H, Hsu S (2013) Mindfulness-based relapse prevention for substance craving. Addict Behav 38(2): 15631571.

17. Witkiewitz K, Lustyk M, Bowen S (2012) Retraining the addicted brain: a review of hypothesized neurobiological mechanisms of mindfulnessbased relapse prevention. Psychol Addict Behav 27(2): 351-365.

18. Westbrook C, Creswell J, Tabibnia G, Julson E, Kober H, et al. (2013) Mindful attention reduces neural and self-reported cue-induced craving in smokers. Soc Cogn Affect Neurosci 8(1): 73-84.

19. Skanavi S, Laqueille X, Aubin H (2011) Mindfulness based interventions for addictive disorders: a review. Encephale 37(5): 379-87.

20. Budney AJ, Moore BA, Vandrey RG, Hughes JR (2003) The time course and significance of cannabis withdrawal. J Abnorm Psychol 112(3): 393-402.

21. Torabi EM (2011) Islamic Meditation. 

(c) (i) This work is licensed under Creative DOI: 10.19080/JOJNHC.2019.10.555786

\section{Your next submission with Juniper Publishers will reach you the below assets}

- Quality Editorial service

- Swift Peer Review

- Reprints availability

- E-prints Service

- Manuscript Podcast for convenient understanding

- Global attainment for your research

- Manuscript accessibility in different formats

( Pdf, E-pub, Full Text, Audio)

- Unceasing customer service

Track the below URL for one-step submission https://juniperpublishers.com/online-submission.php 